\title{
Is there a method in this... madness? On variance between two manuscript copies of a Middle English Psalter*
}

\author{
Kinga Lis
}

John Paul II Catholic University of Lublin, Poland

\begin{abstract}
The objective of the paper is to determine the extent and the possible sources of the intertextual lexical variation between two manuscript copies of a single Middle English Psalter known, among other names, as the Middle English Glossed Prose Psalter. The purpose of the paper can be understood only if one approaches the variance from a medieval perspective on text with respect for the inherent features of manuscript culture and an understanding of the exceptional character of the text analysed in the study, which topics are briefly discussed within the paper. The extent of the variance is measured in relation to the nominal choices attested in the two copies of the text, the rationale behind the variation being sought separately in each case, taking into account the contextual intricacies of all the occurrences of the nouns under analysis.
\end{abstract}

Keywords: Middle English Glossed Prose Psalter, lexical variance, manuscript culture, medieval Psalter

\section{Introduction}

The purpose of the present paper is to determine the extent and the possible sources of the intertextual lexical variation between two manuscript copies of a single text known in the relevant literature under different names ${ }^{1}$ but referred to within the confines of this paper as the Middle English Glossed Prose Psalter. Were it not for the presence of the word manuscript in the previous sentence, the objective of this study could seem to defy logic, which it, however, does not. It is, nevertheless, difficult to attain as it requires of one to adopt a medieval perspective on book with respect for the inherent features of manuscript culture and an understanding of the exceptional character of the text analysed in the study, both of which are discussed in some length in the body of the paper. It needs to be stated already at this

\footnotetext{
* I would like to thank Professor Magdalena Charzyńska-Wójcik for all her help with and comments on this paper.

1 Cf. Charzyńska-Wójcik (2013: 77-84).
} 
point that the nature of manuscript culture is a factor which created conducive conditions for the presence of the lexical variation between the copies of the text analysed here and thus shaped the ground for the present study.

That it is now difficult to imagine how copies of the same text can differ in their lexical layer, and to some extent syntactic one too, can - to resort to an enormous simplification - be ascribed to the invention and the subsequent influence of the printing press. However, before the introduction of the printing culture, things used to look very different and it is impossible to discuss lexical variance between manuscripts without a brief overlook of the pre-print situation (Section 2) as it is against this backdrop that one needs to set the texts discussed in this paper. A short presentation of the texts themselves follows in Section 3. Having discussed the background, I will proceed to the methodology of the research (Section 4), followed closely by the study itself (Section 5), whose results are discussed in the final section (Section 6).

\section{Manuscript culture}

The extent of the variation that can be observed between different manuscript copies of the same medieval text leads one to believe that at the very core of the manuscript culture lies acceptance of variation, ${ }^{2}$ which seems to be in dissonance with the resistance shown in the Middle Ages to 'change in and for itself (Nichols 2011: 1). Nichols (2011) argues for 'mutable stability' which would help to handle this paradox, not forcing one 'to choose between a concept of the work "as somehow above or beyond any manifestation of it," and "the workthat-has-its-being in a given manuscript version"'. For Gellrich (1985), the former approach conveys the concept of the necessity of idealising books which arose out of the material and individual nature of each manuscript: it needed to be seen as an imperfect reflection of an imagined perfect text it represented, as an 'exemplar of a logocentric book-beyond-the-books' (West 2006: 246). On the other hand, the variance between the manuscript copies testifies to each of them being an independent work (Nichols 2011). Thus, medieval manuscripts do represent the same text but the term sameness in the Middle Ages could not be equated with exactness (Nichols 2011:3) and the procedure of establishing an authoritative critical edition is a consequence of applying the modern idea of the book to the products of the medieval reality, without taking the latter into consideration: ${ }^{3}$

2 Cerquiglini (1999: 36, quoted after Nichols 2013: 2) proposes to view it in the following manner:

Medieval writing does not produce variants; it is variance. The endless rewriting to which medieval textuality is subjected, the joyful appropriation of which it is the object, invites us to make a daring hypothesis: the variant is never intermittent (ponctuel).

3 From such an approach stem all the critical remarks hurled at the scribes whose errors and whimsy resulted in the divergences between the texts (Nichols 2011: 20) and who have been accused by textual critics 'of willful disobedience, or cheerful unconcern for the law charging that they should reproduce exactly what they saw in the exemplar (even if it looked like an error), or with plain stupidity' (Greetham 1994: 49), their worst virtue being the 'pernicious desire to do good' (Willis 1992, quoted in Greetham 1994: 49). This is well illustrated in the description of the scribe of the London manuscript of the Middle English Glossed Prose Psalter provided by the first editor of the text: 
the modern critical edition, however erudite and however useful, could not be a faithful representation of an original, but was, rather, a modern reconstruction of an ideal, that from our perspective, never existed. It might evoke the historical moment, but was in no sense of it.

Nichols (2009: 5)

For these reasons, 'rather than seeing scribal literary transmission over time as adulterating the works they addressed' (Nichols 2009: 5), the multiplicity of versions could be interpreted 'as betokening an active milieu of reproduction that could only be called interventionist' (Nichols 2009: 6). Leaving their mark upon the work a scribe was copying was unavoidable and it was not expected of the scribes to avoid it (Nichols 2014: 2). Thus, what is often perceived as negligence should rather be considered a reflection of the socio-cultural context in which the manuscripts were copied and of the care accorded to the work. '[T]echnologies of manuscript reproduction had a dynamic impact in shaping the nature of the work' (Nichols 2009: 5-6). Liuzza (2000: 146-148) would see such scribes as performing an aural transcription and not copying the text literatim, which would result in reproducing the original text exactly as it was represented (visual transcription). An aural transcription, on the other hand, would be the copying of a text read and thus heard and kept in mind. It would transmit not the shape but the sense. Orthographical variation - as a consequence of phonological changes, orthographical innovations and dialectal differences - is not the only sort of variance that stems from this approach. A more conspicuous change can be observed in the area of syntax and of lexicon, the latter being the focus of the present research. As Liuzza (2000: 147) phrases it:

In more extreme cases, the aural transcriber may replace an obsolete word, correct a passage that he or she deems faulty, or change for better or worse a phrase that does not survive the translation from his or her mind to the page. In these cases the scribe is interpreting rather than transcribing; one might even call this work 'editorial'.

In the light of the above, one should perceive the scribe to be a co-author of a text or a translation rather than a transmitter simply, an intermediary granted the right to participate in the creation of the work.

\section{The Middle English Glossed Prose Psalter}

Since it is a commonplace that all manuscript copies differ, the presence of the divergences between the copies of the Middle English Glossed Prose Psalter (MEGPP) does not surprise and does not prevent one from perceiving them as representing the same text. However, the

Judging from the mechanical manner in which he did his copying, he must have been a very ignorant man, who understood neither much Latin nor English, though we cannot blame him for excessive carelessness. In a certain way he has bestowed much attention on his original, and has apparently done his best to make an exact copy, writing letter by letter, so far as he could decipher the original before him, which very likely was difficult to read. He has very often produced most ridiculous results. In such cases he does not seem to have used his brains at all, but to have purposely abstained from making emendations. The blunders in the Latin text of the Psalter are legion.

Bülbring (1891: ix) 
manner in which they differ, especially taking into account what (little) is known about them, provides a strong incentive to investigate the issue.

MEGPP is preserved in only four manuscript copies of which the first two are analysed here: London, British Library, MS Additional 17376 (MEGPP L); Dublin, Trinity College, MS 69 (MEGPP D); Cambridge, Magdalene College, MS Pepys Library 2498; and Princeton, Ms Scheide $143 .^{4}$

The relationship between the different manuscript copies of MEGPP is not straightforward. It is stated by Black and St-Jacques (2012: lv, part 1) that although the London manuscript is the oldest by the date of its composition - 1330-1350 (Black and StJacques 2012: xxviii, part 1, after Hanna 2003: 144), it is the Cambridge copy that is most probably the closest to the English original. Since, as shall become clear, the texts are not copies of one another, Black and St-Jacques (2012) postulate the presence of now-lost archetypal text copies of which started to diverge creating as if two branches. The first of these is now represented by the Cambridge text, derived as if independently (Black and St-Jacques 2012: lii, part 1, after Hanna and Lawton 2003: lxxxvi), whereas the other underwent even further subdivision leading to the composition of the London manuscript on the one hand and the Dublin and Princeton copies on the other. Such a complex web of relationships between the text envisaged by Black and S-Jacques (2012) stems from the characteristics of each of the manuscript copies.

Despite the fact that relatively little is certain and agreed upon with respect to MEGPP, there is no doubt that its most characteristic feature are the glosses whose readings often replace the original Latin lemmata. In fact it is the nature of the glosses and their treatment in the four manuscripts that to a great extent enabled Black and St-Jacques among other scholars to draw the conclusions concerning the intertextual relations between the manuscripts. Both the Cambridge and London manuscripts incorporate the readings of the gloss into the translation without rendering the lemmata, whereas the usual practice for the Dublin and Princeton manuscripts is to translate both the lemma and the gloss. Based on the number of the glosses present in the London and the Cambridge manuscripts, Black and St-Jacques (2012) regard the two as closer to the original.

Moreover, a linguistic analysis of the texts also prompts one to consider the Dublin and Princeton manuscripts as further from the Latin exemplar due to their use of less learned language, which is 'closer to everyday speech during a time when English became less influenced by Latin and French' (Black and St-Jacques 2012: liii, part 1). What is especially important in the context of the present research is the fact that both these manuscript copies employ fewer Latinate words than the Cambridge and the London manuscripts do, which leads Black and St-Jacques (2012: liii, part 1) to believe that they are 'from a later, truncated, and simplified version with fewer Latin and French words'. ${ }^{5}$

4 The study is limited to the analysis of only two manuscript copies of the text as these are the manuscripts edited by Bülbring (1891), whose work is generally trusted. The text of the Cambridge MS with variants from the remaining manuscript copies is available in Black and St-Jacques (2012) but since this edition diverges in many places from Bülbring's (1891) edition it was decided to base the study exclusively on the latter (see Section 4).

5 For a discussion of the etymological make-up of the nominal layer of the first fifty Psalms in the London and Dublin copies of MEGPP, see Lis (in press). 
Another factor which renders the situation still more complex is the presence of a French intermediary which the English translator had at their disposal and which to some extent influenced the shape of the English rendition. ${ }^{6}$ The treatment of the glosses in this translation mirrors the situation described for the London and the Cambridge manuscripts. The text of the French glossed Psalter is preserved in Paris, Bibliothèque nationale, MS fonds français 6260 (a 15th-century copy of a 13th-century text according to Berger 1884) and, as reported by Sutherland (2015: 120-135), in London, British Library, MS Additional 44949 (14th century). It needs to be borne in mind throughout the paper that the time gap between the French extant manuscript copy/copies and the ME manuscripts of MEGPP (MEGPP L dates to the middle of the 14th century and MEGPP D to the close of that century) may distort the results obtained in the research.

\section{Methodology and the data}

MEGPP in the two manuscript copies analysed here is the focal point of the present study. Yet, as is already evident on the basis of the information provided in the preceding section, the research could not dispense with taking into account also the Latin and the French texts. Whereas the ME Psalters analysed here are taken from Charzyńska-Wójcik (2013), who used Bülbring's (1891) edition as the basis, and juxtaposed with Black and St-Jacques' (2012) edition, the French Psalter used in the process of the research came in the digitised manuscript form which was compared with its text presented in Black and St-Jacques (2012). Since no edition of the complete Latin text of the glossed Psalter is available, Black and St-Jacques (2012) providing only the glossed verses, it was necessary to use, for the purposes of the study, the text of the standard Gallican Psalter, also as available in Charzyńska-Wójcik (2013). This Latin text constituted the first step in the preparation of the database since using the underlying Latin as a point of departure allowed me to compare only the parallel lexical items in all the relevant Psalters and to determine which readings in the translations were non-standard despite the fact that they are not signposted as 'glossed' in Black and St-Jacques' (2012) edition.

The study concentrates exclusively on nouns in the first 50 Psalms, with occurrences of the same Latin lemma grouped under one headword, comparing only the parallel items in all four texts, i.e. the Latin, French and two ME Psalter copies. ${ }^{7}$ Since the shape of the Latin text determined the number of the lexical items analysed in the study, the complete database contains 2877 Latin nouns, with proper nouns excluded, and the items corresponding to them in the translations. As might be expected, not all 2877 Latin nouns find nominal equivalents in the renditions: gerunds, adjectives, nouns and whole phrases are used at times to convey the

\footnotetext{
6 Although Deanesly (1920: 143) states unhesitatingly that MEGPP 'was translated from a French original' and Reuter (1938: [1]) contends that 'the so called Earliest Complete English Prose Psalter [i.e. MEGPP - my addition] was mainly based on a French version', I would not venture to draw hasty conclusions in this respect. As proved in St-Jacques (1989), MEGPP might be greatly indebted to the French glossed Psalter but does not follow it blindly for instance as far as some issues related to word-order are concerned.

7 The following dictionaries have been employed for Latin, French and Middle English Psalters respectively: Whitaker's WORDS: Latin-to-English \& English-to-Latin Dictionary, Dictionnaire du Moyen Français, the Middle English Dictionary and the Oxford English Dictionary.
} 
notions expressed by nouns in the Latin text. Additionally, there are also such Latin items which do not find corresponding lexical items in the renditions for a variety of reasons ranging from the manuscript being damaged, through scribal omission, to the heterodoxy of the translation. All such cases are duly recorded in the database. In the next stage of the research I limited my study area to the divergent cases, whose number equals 275 . However, not all of the cases were subject to further analysis as only 145, representing 70 distinct Latin lemmata, met all the methodological criteria established for the purposes of the study, i.e.

(i) they were nouns according to the labels provided in the Middle English Dictionary and the Oxford English Dictionary,

(ii) they were not the renderings of the Latin glosses: due to the divergences in the treatment of glosses between the manuscripts of the text and to the fact that I do not have at my disposal the original Latin text from which the Middle English Glossed Prose Psalter was rendered I could not analyse these cases.

Additionally, also divergences in the renderings of the nouns Deus, Dei and dominus, domini have been disregarded as due to the fact that the base Latin text is not available in any edition in its entirety and taking into account the variation between different copies of the Gallican Psalter as regards the use of the two nouns, it would be impossible for me to determine with any certainty the reasons for the divergence between the two manuscripts of MEGPP with respect to those lexical items.

Since any study which aims at determining the reasons for the intertextual divergences in lexical choices necessitates taking into consideration the context in which these occur, I needed to analyse the data I obtained from the perspective of the number of occurrences each Latin lemma has in the body of the first 50 Psalms as all of these had to be scrutinised. This procedure enabled me to further narrow the database as the analysis of low frequency items had to be limited to an observation of the formal similarities between the Latin, French and ME items: the presence of a formally similar item in either of the remaining texts might have encouraged the use of a given ME noun, either a cognate to the former or a borrowing. The study proper is discussed in the following section.

\section{The study}

\subsection{All divergent cases}

All the divergent pairs of items, along with the Latin lemmata and the nouns employed in the French Psalter, are presented in Table 1 below. The table provides the verse number (column 2) in which the diverging lexical choices occur, the Latin lemmata along with the number of the occurrences analysed, i.e. only those occurrences which fulfil the methodological criteria are taken into account here (column 3), the ME items employed in MEGPP L (column 4) and MEGPP D (column 5) as well as the renderings used in the French translation (column 6). The final column provides the information as regards the potential influence exerted either by the Latin original or the French Psalter on the lexical choices in MEGPP, focusing on the formal similarities between the nouns employed in these four texts. The items to which the 
information relates are italicised. The nouns presented on the grey background (33 distinct Latin lemmata) are those whose low number of occurrences prohibits further contextsensitive analysis. ${ }^{8}$

Table 1: Divergent cases

\begin{tabular}{|c|c|c|c|c|c|c|}
\hline $\mathrm{N}^{0}$ & Verse & $\begin{array}{l}\text { Latin and } n^{0} \text { of valid } \\
\text { occurrences }\end{array}$ & MEGPP L & MEGPP D & French & formal influence \\
\hline 1. & 49.19 & adulter, adulteri (1) & spŏuse-brēker(e & ?* wanter $(\mathrm{e}$ & avoutire & \\
\hline 2. & 31.4 & aerumna, aerumnae (1) & $(!)^{9}$ caitiftè & mischēf & chetiveté & French \\
\hline 3. & 9.24 & anima, animae (50) & soul $(\mathrm{e}$ & herte & ame & \\
\hline 4. & 13.5 & aspis, aspid[i/o]s (1) & aspide, nāddre & nāddre & serpent & Latin \\
\hline 5. & 21.19 & auxilium, auxili(i) (3) & hēlth(e & help & aide & \\
\hline 6. & 38.3 & bonum, boni (10) & gōd & gōdnes(se & bien & \\
\hline 7. & 13.11 & captivitas, captivitatis (1) & caitīfnes(se & thraldōm & chetiveté & French \\
\hline \multirow[t]{2}{*}{8.} & 3.7 & \multirow{2}{*}{ causa, causae (4) } & \multirow[t]{2}{*}{ enchēsŏun } & \multirow[t]{2}{*}{ cause } & \multirow[t]{2}{*}{ cause } & \multirow[t]{2}{*}{ French and Latin } \\
\hline & 9.4 & & & & & \\
\hline 9. & 19.8 & currus, currus (1) & carre & cart & chariot & \\
\hline \multirow[t]{2}{*}{10.} & 2.12 & \multirow{2}{*}{ disciplina, disciplinae (4) } & \multirow[t]{2}{*}{ disciplīne } & \multirow[t]{2}{*}{$\operatorname{lō} r(e$} & \multirow[t]{2}{*}{ discipline } & \multirow[t]{2}{*}{ French and Latin } \\
\hline & 49.18 & & & & & \\
\hline \multirow[t]{8}{*}{11.} & 9.29 & \multirow{8}{*}{ dolus, doli (8) } & \multirow[t]{2}{*}{ trecheri(e } & \multirow[t]{8}{*}{ gile } & \multirow[t]{2}{*}{ tricherie } & \multirow[t]{2}{*}{ French } \\
\hline & 14.3 & & & & & \\
\hline & 23.4 & & \multirow[t]{2}{*}{ gìlerī(e } & & deçoite & \\
\hline & 31.2 & & & & decerte / deçoite & \\
\hline & 33.13 & & \multirow[t]{4}{*}{ trecheri(e } & & barateur & \\
\hline & 34.23 & & & & \multirow[t]{2}{*}{ decerte(s) / deçoite } & \\
\hline & 35.3 & & & & & \\
\hline & 49.20 & & & & tricherie & French \\
\hline 12. & 10.5 & filius, fili (18) & chïld & sŏne & enfant & \\
\hline 13. & 18.4 & finis, finis (14) & cŏntrē(e & ēnde & part & \\
\hline 14. & 36.21 & fumus,fumi (2) & smōke & smēk(e & fumee $\backslash$ & \\
\hline 15. & 36.8 & furor, furoris (1) & wōdship(e & wōdnes(se & desverie & \\
\hline \multirow[t]{2}{*}{16.} & 9.28 & \multirow{2}{*}{$\begin{array}{l}\text { generatio, generationis } \\
(5)\end{array}$} & \multirow[t]{2}{*}{ kinde } & \multirow[t]{2}{*}{ kin } & generation & \\
\hline & 9.28 & & & & - & \\
\hline 17. & 3.3 & & glōrie & joile & joie & $\begin{array}{l}\text { Latin (L) vs. } \\
\text { French (D) }\end{array}$ \\
\hline & 7.5 & & & & gloire & French and Latin \\
\hline & 8.6 & & & & & (L) \\
\hline & 16.17 & & & & & \\
\hline & 18.1 & & & & & \\
\hline & 20.5 & & & & & \\
\hline & 20.5 & gloria, gloriae (21) & & & & \\
\hline & 23.9 & & & & & \\
\hline & 23.10 & & & & & \\
\hline & 25.8 & & & & & \\
\hline & 28.2 & & & & & \\
\hline & 28.2 & & & & & \\
\hline & 28.8 & & & & & \\
\hline & 29.15 & & & & & \\
\hline
\end{tabular}

8 The low frequency items which were excluded are those represented by only one or two occurrences, which prohibits further analysis since it is not possible, in the case of these nouns, to draw any conclusions as regards the motivation behind the divergence.

9 The information is provided after Bülbring (1891), who indicates the scribal spelling errors in this way: (Bülbring 1891) London MS. chaitiste (with a long $s$ ). 


\begin{tabular}{|c|c|c|c|c|c|c|}
\hline & 44.15 & & & & \multirow[t]{2}{*}{ joie } & \multirow{2}{*}{$\begin{array}{l}\text { Latin (L) vs. } \\
\text { French (D) }\end{array}$} \\
\hline & 48.15 & & & & & \\
\hline & 48.17 & & & & \multirow[t]{2}{*}{ gloire } & \multirow{2}{*}{$\begin{array}{l}\text { French and Latin } \\
\text { (L) }\end{array}$} \\
\hline & 48.18 & & & & & \\
\hline 18. & 13.5 & guttur, gutturis (2) & gorğe & thrōte & gorge & French \\
\hline 19. & 28.2 & hono[r/s], honoris (5) & honŏur & worship $(\mathrm{e}$ & honneur & French and Latin \\
\hline 20. & 26.11 & hostia, hostiae (1) & offrende & sacrifīce & offrande & French \\
\hline 21. & 37.7 & $\begin{array}{l}\text { illusio, } \\
\text { illusionis/[inlusio, } \\
\text { inlusionis] }{ }^{10}(1)\end{array}$ & illūsiŏun & $\operatorname{dēceit}(\mathrm{e}$ & illusion & French and Latin \\
\hline 22. & 38.9 & imago, imaginis (1) & liknes(se & imāğe & image & French and Latin \\
\hline 23. & 5.12 & impietas, impietatis (2) & ivel & wikkednes(se & mal & \\
\hline 24. & 29.5 & $\begin{array}{l}\text { indignatio, indignationis } \\
\text { (1) }\end{array}$ & dignāciŏun & indignāciŏun & indignation & French and Latin \\
\hline 25. & 7.17 & $\begin{array}{l}\text { iniquitas, iniquitatis } \\
(33)^{11}\end{array}$ & wikkenes $^{12}$ & wikkednes(se & mauvaiseté & \\
\hline 26. & 33.9 & inopia, inopiae (2) & misēse & nēd(e & mesaise & French \\
\hline 27. & 21.2 & $\begin{array}{l}\text { insipientia, insipientiae } \\
(1)\end{array}$ & unwit & unwīsdōm & non-savoir [v.] & \\
\hline 28. & 26.14 & ira, irae (12) & ìre & wratthe & ire & French and Latin \\
\hline 29. & 7.12 & judex, judicis (2) & jūğe & dōmes-man & juge & French \\
\hline 30. & 9.4 & \multirow{15}{*}{ judicium, judici(i) (15) } & \multirow[t]{15}{*}{ jūğement } & \multirow[t]{15}{*}{ dōm } & \multirow[t]{15}{*}{ jugement } & \multirow[t]{15}{*}{ French } \\
\hline & 9.8 & & & & & \\
\hline & 9.17 & & & & & \\
\hline & 9.27 & & & & & \\
\hline & 16.3 & & & & & \\
\hline & 17.25 & & & & & \\
\hline & 18.10 & & & & & \\
\hline & 24.10 & & & & & \\
\hline & 32.5 & & & & & \\
\hline & 34.26 & & & & & \\
\hline & 35.6 & & & & & \\
\hline & 36.6 & & & & & \\
\hline & 36.29 & & & & & \\
\hline & 36.32 & & & & & \\
\hline & 47.10 & & & & & \\
\hline \multirow[t]{3}{*}{31.} & 48.12 & \multirow{3}{*}{ jumentum, jumenti (4) } & \multirow[t]{3}{*}{ mēre } & bēst(e & \multirow[t]{3}{*}{ jument } & \\
\hline & 48.21 & & & & & \\
\hline & 49.11 & & & cŏu & & \\
\hline \multirow[t]{3}{*}{32.} & 7.9 & \multirow{3}{*}{ justitia, justitiae (32) } & rightfulnes(se & right-wīsnes(se & \multirow[t]{3}{*}{ droiture } & \\
\hline & 16.1 & & right & rightfulnes(se & & \\
\hline & 44.9 & & rightfulnes(se & right & & \\
\hline \multirow[t]{2}{*}{33.} & 24.7 & \multirow{2}{*}{ juventus, juventutis (2) } & \multirow[t]{2}{*}{ yŏngthe } & \multirow[t]{2}{*}{ yŏuth } & \multirow[t]{2}{*}{ jeunesse } & \\
\hline & 42.4 & & & & & \\
\hline 34. & 9.16 & laque[us/um], laquei & gnāre & grīn(e & - & \\
\hline
\end{tabular}

10 The shape of the Latin lemma presented here indicates that the different versions of the Gallicanum gathered in Charzyńska-Wójcik (2013) diverge at this point using different phonological forms of the noun.

11 There is one more occurrence of this Latin noun, which has, however, been excluded from the study due to the fact that the shape in which its rendering is given in MEGPP D suggests that it translates both the lemma and the gloss, whereas there is no information in Black and St-Jacques (2012) about this verse being glossed in the Latin text.

12 Bülbring (1891: 7) states that wikkenes is a result of a scribal mistake. However, since the word is listed in the Middle English Dictionary, it is treated independently of wikkednes(se in this study. 


\begin{tabular}{|c|c|c|c|c|c|c|}
\hline & 10.7 & \multirow[t]{6}{*}{$(7)^{13}$} & drōpe & & \multirow[t]{5}{*}{ lacs } & \\
\hline & 17.6 & & trappe & & & \\
\hline & 24.16 & & \multirow[t]{3}{*}{ gnāre } & & & \\
\hline & 30.5 & & & & & \\
\hline & 34.9 & & & & & \\
\hline & 34.9 & & $(!)^{14}$ gnāre & & - & \\
\hline 35. & 1.2 & lex, legis (8) & wil(le & laue & loi & \\
\hline 36. & 23.3 & loc[us/um], loci (8) & stēde & plāce & lieu & \\
\hline 37. & 37.7 & lumbus, lumbi (1) & $(!)^{15}$ ? bak & lēnd(e & rein & \\
\hline 38. & 17.46 & lutum, luti (1) & lōm & clei & boue & \\
\hline 39. & 14.2 & macula, maculae (1) & wem & sinne & tache & \\
\hline 40. & 44.6 & $\begin{array}{l}\text { mansuetudo, } \\
\text { mansuetudini (1) }\end{array}$ & softnes(se & mëknesse & debonnaireté & \\
\hline \multirow[t]{2}{*}{41.} & 38.4 & \multirow{2}{*}{$\begin{array}{l}\text { meditatio, meditationis } \\
(3)\end{array}$} & \multirow[t]{2}{*}{ thought } & \multirow[t]{2}{*}{$\operatorname{mind}(\mathrm{e}$} & \multirow[t]{2}{*}{ pensee } & \\
\hline & 48.3 & & & & & \\
\hline 42. & 25.7 & mirabile, mirabilis (3) & merveille & wŏnder & merveille & French \\
\hline 43. & 50.2 & $\begin{array}{l}\text { miseratio, miserationis } \\
(3)\end{array}$ & pitē & mercī & merci & French \\
\hline 44. & 11.5 & miseria, miseriae (1) & caitiftè & wrecchednes(se & chetiveté & French \\
\hline 45. & 23.3 & mons, montis (12) & mŏuntain(e & hil(le & montagne & French \\
\hline \multirow[t]{4}{*}{46.} & 9.25 & \multirow{4}{*}{$\begin{array}{l}\text { multitudo, multitudinis } \\
(9)\end{array}$} & \multirow[t]{2}{*}{ muchelhēd(e } & muchelnes(se & \multirow[t]{4}{*}{ multitude } & \\
\hline & 32.16 & & & grētnes(se & & \\
\hline & 48.6 & & \multirow[t]{2}{*}{ muchelnes(se } & & & \\
\hline & 50.2 & & & & & \\
\hline 47. & 17.53 & natio, nationis (1) & cŏntrē $(e$ & nāciŏun & nation & French and Latin \\
\hline \multirow[t]{3}{*}{48.} & 30.14 & \multirow{3}{*}{$\begin{array}{l}\text { obprobrium,obprobri(i)/ } \\
<\text { opprobrium,opprobri(i } \\
)>>^{16}(3)\end{array}$} & \multirow{2}{*}{ reprōche } & \multirow[t]{3}{*}{ reprēve } & \multirow[t]{3}{*}{ reproche } & \multirow[t]{3}{*}{ French } \\
\hline & 38.12 & & & & & \\
\hline & 43.15 & & $(!)^{17}$ reprōche & & & \\
\hline 49. & 48.4 & parabola, parabolae (1) & parāble & ensaumple & parole & Latin \\
\hline 50. & 15.5 & pars, partis (2) & part & pārtīee & part & French and Latin \\
\hline 51. & 9.19 & patientia, patientiae (1) & sufferaunce & pācience & patience & French and Latin \\
\hline 52. & 14.6 & pecunia, pecuniae (1) & trēsǒur & monei(e & avoir & \\
\hline \multirow[t]{2}{*}{53.} & 23.1 & \multirow{2}{*}{$\begin{array}{l}\text { plenitudo, plenitudinis } \\
(2)\end{array}$} & plentē & \multirow[t]{2}{*}{ plentēvŏusnes(se } & \multirow[t]{2}{*}{-} & \\
\hline & 49.13 & & fulnes(se & & & \\
\hline 54. & 46.3 & populus, populi (23) & folk & nāciŏun & peuple & \\
\hline \multirow[t]{2}{*}{55.} & 2.6 & \multirow{2}{*}{$\begin{array}{l}\text { praeceptum, praecepti } \\
\text { (3) }\end{array}$} & \multirow[t]{2}{*}{ commaundement } & hēst(e & commandement & French \\
\hline & 18.9 & & & & & \\
\hline 56. & 17.3 & & hëlth(e & help & force & \\
\hline & 26.1 & salus, salutis (15) & help & hēlth(e & salut & \\
\hline & 32.17 & & hèlth(e & help & santé & \\
\hline 57. & 23.5 & $\begin{array}{l}\text { salutare, salutaris } \\
/[\text { salvator, salvatoris } \\
]^{18}(15)\end{array}$ & help & hēlth(e & sanctité & \\
\hline
\end{tabular}

${ }_{13}$ There is one occurrence of this item which, although glossed in Latin, does not preserve glossing in the translation so I have decided not to exclude it from the study.

${ }^{14}$ (Bülbring 1891) London MS. graue.

15 (Bülbring 1891) London MS. uaches.

16 The alteration between the different versions of the Gallican Psalters indicated here obtains for all occurrences of this Latin lemma. Interestingly, there are two more verses in the Psalter in which this noun is employed but in those the form opprobrium, opprobri( $i$ ) is the dominant reading and what is more, both those occurrences are rendered by means of a gerund in MEGPP L, whereas in MEGPP D only one of them is.

17 London MS depruse.

18 This alteration between the different versions of the Gallican Psalter obtains for two occurrences of this Latin lemma: this one - verse 23.1 and the one in verse 26.15 . 


\begin{tabular}{|c|c|c|c|c|c|c|}
\hline 58. & 46.8 & sedes, sedis (3) & sēgğe & sēte & siege & French \\
\hline \multirow[t]{6}{*}{59.} & 8.8 & \multirow{6}{*}{ semita, semitae (7) } & \multirow[t]{6}{*}{ bì-stì } & \multirow[t]{6}{*}{ pāth } & \multirow[t]{6}{*}{ sente } & \\
\hline & 16.6 & & & & & \\
\hline & 22.3 & & & & & \\
\hline & 24.4 & & & & & \\
\hline & 26.17 & & & & & \\
\hline & 43.20 & & & & & \\
\hline 60. & 5.11 & $\begin{array}{l}\text { sepulcrum, } \\
\text { sepulcri/<[sepulchrum,s } \\
\text { epulchri] }>^{19}(3)\end{array}$ & grāve & biriel(s & cercueil & \\
\hline 61. & 10.7 & spiritus, spiritus (9) & gōst & spirit & esprit & French and Latin \\
\hline 62. & 48.11 & terra, terrae $(51)^{20}$ & èrthe & lōnd & terre & \\
\hline \multirow[t]{2}{*}{63.} & 5.8 & \multirow{2}{*}{ timor, timoris (9) } & \multirow[t]{2}{*}{ dŏut(e } & \multirow[t]{2}{*}{ drēd(e } & crainte & \\
\hline & 18.10 & & & & peur & \\
\hline 64. & 17.5 & torrens, torrentis (2) & wel(le & rivēr(e & foiffaiz $^{21}$ / fontaine & \\
\hline 65. & 14.6 & usura, usurae (1) & oker & $\bar{u}$ sūre & usure & French and Latin \\
\hline 66. & 44.11 & varietas, varietatis (1) & selcŏuthnesse & diversenes & diversité & French \\
\hline \multirow[t]{3}{*}{67.} & 14.3 & \multirow{3}{*}{ veritas, veritatis (16) } & \multirow[t]{3}{*}{ sōthnes(se } & \multirow[t]{3}{*}{ sōthfastnes(se } & \multirow[t]{3}{*}{ verité } & \\
\hline & 24.11 & & & & & \\
\hline & 30.6 & & & & & \\
\hline 68. & 37.12 & vis, vis (1) & förce & strength $(\mathrm{e}$ & force & French \\
\hline \multirow[t]{2}{*}{69.} & 21.26 & \multirow{2}{*}{ votum, voti (2) } & \multirow[t]{2}{*}{ vŏu(e } & \multirow[t]{2}{*}{ wōn(e } & \multirow[t]{2}{*}{ voeu } & \multirow[t]{2}{*}{ French } \\
\hline & 49.15 & & & & & \\
\hline \multirow[t]{5}{*}{70.} & 10.8 & \multirow{4}{*}{ vultus, vultus (9) } & \multirow[t]{5}{*}{ semblaunce } & fāce & \multirow[t]{2}{*}{ face } & French \\
\hline & 20.6 & & & \multirow[t]{3}{*}{ chēre } & & \\
\hline & 20.12 & & & & vue & \\
\hline & 44.14 & & & & face & \\
\hline & 33.16 & $\begin{array}{ll}\text { vultus, } & \text { vultus/[facies, } \\
\text { faciei }^{22} & \end{array}$ & & fāce & voult & \\
\hline
\end{tabular}

It is evident on inspection of the data presented above that the formal similarities between Romance lexical items used in the Latin and French texts and the nouns available for the speakers of English could undoubtedly have played a vital role in the process of vocabulary selection. Since, as reported by Black and St-Jacques (2012: liii-liv, part 1), the Dublin manuscript shows 'a preference for OE over Latin and French words', it comes as no surprise that also fewer Romance items are employed there in the cases where the two manuscript copies diverge as regards lexical choices. Table 2 presents the relevant numerical data concerning the number of lexical items employed in MEGPP L and MEGPP D which exhibit formal similarity to the nouns employed in the Latin and French texts and whose presence in the renditions might, therefore, have been motivated by this resemblance. The number given after a forward slash corresponds to the total number of Romance borrowings among the diverging items in each manuscript copy.

19 This alteration between the different versions of the Gallican Psalter obtains only in the case of this occurrence of the Latin lemma.

20 There is one occurrence of this item which, although glossed in Latin, does not preserve the glossing in the translation, so I decided not to exclude it from the study.

${ }_{21}$ This is not a dictionary lemma since the word form given in the manuscript is a result of a scribal mistake and cannot be lemmatised to any noun listed in the Dictionnaire du Moyen Français.

22 This alteration between the different versions of the Gallican Psalter obtains for two occurrences of this Latin lemma: this one (verse 33.16) and the one in verse 43.5. 
Table 2: Nouns exhibiting formal similarity to the items employed in the French and Latin texts

\begin{tabular}{lll}
\hline Type of influence & MEGPP L & MEGPP D \\
\hline French & 36 & 6 \\
Latin & 5 & 0 \\
French and Latin & 18 & 9 \\
sum & $59 / 84$ & $15 / 56$ \\
\hline
\end{tabular}

\subsection{Divergent cases - further analysis}

As regards other factors that might have contributed to the divergent lexical choices between the different copies of MEGPP, the situation is not so straightforward. For many among the Latin lemmata showing divergent lexical items in the two manuscripts of MEGPP listed in Table 1 I cannot point to a principle governing the divergence. Let me note that only 37 items listed in Table 1 can be taken into consideration due to the low number of occurrences of the remaining 33 Latin nouns. An analysis of all the occurrences of these items does not reveal any contextual justification for the divergent choices in the case of as many as 33 (out of 37) Latin lemmata. Table 3 below lists these 33 Latin nouns presented above for whose corresponding divergent items in the relevant verses in MEGPP L and MEGPP D I cannot account.

Table 3: Divergent lexical choices which cannot be accounted for

\begin{tabular}{|c|c|c|}
\hline $\mathbf{N}^{\mathbf{o}}$ & Latin lemma & comment \\
\hline 1. & auxilium, auxili(i) (3) & $\begin{array}{l}\text { no contextual motivation: auxilium, auxili(i) 'help, assistance' with the } \\
\text { meaning of 'God's help' is also used in one of the other verses }\end{array}$ \\
\hline 2. & bonum, boni (10) & no contextual motivation: semantic context is the same \\
\hline 3. & causa, causae $(4)$ & $\begin{array}{l}\text { no contextual motivation: } 3 \text { out of } 4 \text { occurrences are employed with the } \\
\text { same meaning }\end{array}$ \\
\hline 4. & disciplina, disciplinae (4) & $\begin{array}{l}\text { no certain contextual motivation for the divergence although it cannot be } \\
\text { dismissed altogether: two occurrences (both in verse 17.39) render the } \\
\text { explicit concept of God's teachings; in the remaining two verses, i.e. the } \\
\text { divergent cases ( } 2.12 \text { and } 49.18 \text { ), this is only implied, which could suggest } \\
\text { that the scribe of MEGPP D attempted to differentiate between the two }\end{array}$ \\
\hline 5. & dolus, doli & $\begin{array}{l}\text { the reason for the intertextual divergence cannot be given since MEGPP L } \\
\text { and MEGPP D use different items in all the cases; the intratextual variation } \\
\text { in MEGPP L, on the other hand, seems to be contextually motivated }\end{array}$ \\
\hline 6. & filius, fili & $\begin{array}{l}\text { no certain contextual motivation for the divergence: it is not number- } \\
\text { sensitive, does not correspond exactly to the data from French, nor is, as far } \\
\text { as can be glimpsed from the data, context-sensitive; however, the scarcity of } \\
\text { the data does not allow to draw decisive conclusions }\end{array}$ \\
\hline 7. & finis, finis & no contextual motivation \\
\hline 8. & generatio, generationis & $\begin{array}{l}\text { no contextual motivation; there is no consistency in the choices of the } \\
\text { scribe of MEGPP D: both kin and kinde are employed in exactly the same } \\
\text { semantic contexts in different verses }\end{array}$ \\
\hline 9. & gloria, gloriae & $\begin{array}{l}\text { no contextual motivation: both glörie and joi(e appear in MEGPP D to } \\
\text { render the rex glorie 'the king of glory' phrase and in all the remaining } \\
\text { contexts MEGPP D always chooses joi(e over glorie; the latter noun, } \\
\text { however, is employed consistently throughout in MEGPP L }\end{array}$ \\
\hline 10. & iniquitas, in & no contextual motivation \\
\hline
\end{tabular}


11. ira, irae

12. judicium, judici(i) (15)

13. jumentum, jumenti (4)

14. justitia, justitiae

15. laque[us/um], laquei

16. lex, legis (8)

17. loc[us/um], loci

18. meditatio, meditationis

19. mirabile, mirabilis

20. mons, montis

21. multitudo, multitudinis no contextual motivation

it is impossible to point to a reason - apart from MEGPP L's adherence to the formally similar item employed in the French Psalter - since both texts employ the variant English equivalents consistently throughout

no contextual motivation: taking into account the fact that the meaning of this Latin lemma is limited to 'mule; beast of burden', which prevents a broader interpretation of any of the relevant verses, the divergences between the manuscripts cannot be accounted for; it might be that the scribes took into consideration slightly altering shades of meaning but in doing so acted on different principles

no contextual motivation: there appears to be no guiding principle behind the scribe's choices, the manuscripts agreeing in the majority of cases (29) in semantically analogous contexts though employing the three nouns freely

although I cannot account for the divergences between the two texts as regards the gnäre-grin (e opposition, the alteration in the noun choices in MEGPP L seems to have been context-motivated: MEGPP L employs gnäre for a snare used by one's enemies to one's detriment, drōpe to refer to the punishment sent by God, and trappe for 'snares of death'

no contextual motivation: the concept of lex Dei, lex domini 'God's law' in all the remaining cases is rendered by laue not wille

no contextual motivation: locus, loci 'place, territory/locality/neighborhood/region' is employed with the sense of 'God's dwelling place' also in two other verses

no contextual motivation: phrase meditacio cordis mei 'my heart's meditation' appears both in verse 18.5 and in verse 48.3 and is treated differently in MEGPP D in each case, rendered both by thought and mind(e

no contextual motivation: all the occurrences of mirabile, mirabilis 'miracle, wondrous deed' refer to the works of God

no contextual motivation: both hil(le and mountain(e are used in the two manuscripts to render the concept of mons sanctus 'holy mountain/hill' as a dwelling place of God, which is also the context in verse 23.3

although it is not possible to posit a guiding principle behind the divergent choices, a tendency in MEGPP D to employ grètnes(se in the context of positive qualities, features may be observed, which, however, is not always respected (grētnes(se could also be employed in verse 5.7)

22. obprobrium,obprobri(i)/<opp no contextual motivation can be postulated: too little data and exclusively robrium,opprobri(i)>

23. populus, populi

24. praeceptum, praecepti

25. salus, salutis

26. salutare, salutaris /[salvator, salvatoris]

27. sedes, sedis

28. semita, semitae analogous contexts

no contextual motivation: the Latin noun populus, populi 'people, nation' is employed with reference to nations in multiple cases (e.g. 17.48, 17.51, $43.3,43.14,44.7)$, and only once it is rendered by nāciŏun in MEGPP D

no contextual motivation: all instances of praeceptum, praecepti 'teaching, lesson, precept; order, command' refer to God's commandments/precepts no apparent contextual motivation

no apparent contextual motivation

no contextual motivation: all three occurrences refer to the place of God's habitation

no contextual motivation between the manuscripts and the single other occurrence of semita, semitae 'path', whose rendering is congruent between the two texts, appears in an altogether different context 

29. spiritus, spiritus
30. terra, terrae

31. timor, timoris

32. veritas, veritatis

33. vultus, vultus no contextual motivation

no contextual motivation: the noun lōnd is employed twice to render terra, terrae 'earth, land, ground; country, region': once in the verse in question (48.11) and once - in both manuscripts - in verse 15.2; the semantic contexts are disparate: in the former it is God's land that is referred to and in the latter the land as a property of men; in the majority of cases in such contexts the noun êrthe is employed invariably

no contextual motivation: in the majority of occurrences (6 out of 9, among which are the two divergent cases) timor, timoris 'fear; dread' is an expression of reverence to God, due to God; in the remaining three cases it is a dread or fear whose source is different

no contextual motivation: the 'truth' as applied to man and the 'truth' as a virtue of God are always rendered by the same noun (sōthnes(se) in MEGPP L and indiscriminately by two different nouns, sōthnes(se and sōthfastnes(se, in MEGPP D

no contextual motivation; neither is there correspondence between the lexical choices in the French text and either of the ME manuscripts

There are, however, four Latin lemmata, the divergences between whose renderings in MEGPP L and MEGPP D appear to have some motivation.

\subsubsection{Divergences in the renderings of anima, animae}

The first noun whose divergent renderings between MEGPP L and MEGPP D appear to have been motivated by contextual differences among the occurrences is anima, animae 'soul, spirit, vital principle; life; breathing; wind, breeze; air'. The expected translation of this Latin noun into English is the word soul, whereas in verse 9.24 MEGPP D uses the noun heart, despite the fact that what is referred to is invariably a human soul. Having no access to the original Latin text, the verse in question being not edited in Black and St-Jacques (2012), I can posit only the following motivation behind the divergence. Among the 50 occurrences of anima, animae only one appears in a noun-noun construction, where it is a Possessor: ${ }^{23}$

(1) 9.24: Quoniam laudatur peccator in desideriis [ABL] anime /<animæ[ae] $[\mathrm{GEN}] /$ sue $/<$ suæ[ae $]>/$ : \& iniquus benedicitur.

'Because a sinner is praised in his soul's desires, the treacherous is blessed.' ${ }^{24}$

There are, however, eight such occurrences of the noun cor, cordis 'heart; mind/soul/spirit; intellect', all of which are listed in Table 4.

Interestingly, in verse 20.2, which is not given in Black and St-Jacques (2012) either, there are divergent readings in different copies of the Gallican Psalter, some of them exhibiting anima, animae rather than cor, cordis. This gives one the grounds to suspect that the structural and semantic similarities between the occurrences of cor, cordis listed above and the occurrence of anima, animae in question led the scribe of MEGPP D to connect them and as

\footnotetext{
${ }^{23}$ In fact there is one more context where anima, animae appears in noun-noun construction (34.14) but there it is used in the dative case and is a Goal.

24 The English translation provided here and in the following examples is given after Cunyus (2009).
} 
Table 4: Noun-noun structures with cor, cordis

\begin{tabular}{cll}
\hline $\mathrm{N}^{\circ}$ & verse & Latin text \\
\hline 1. & 18.15 & meditacio (NOM) cordis (GEN) \\
2. & 20.2 & desiderium (NOM) cordis [animae] (GEN) \\
3. & 24.18 & tribulaciones (NOM) cordis (GEN) \\
4. & 32.11 & cogitaciones (NOM) cordis (GEN) \\
5. & 36.4 & peticiones (ACC) cordis (GEN) \\
6. & 37.8 & a gemitu (ABL) cordis (GEN) \\
7. & 43.23 & abscondita (ACC) cordis (GEN) \\
8. & 48.3 & meditacio (NOM) cordis (GEN) \\
\hline
\end{tabular}

they were copying the text they replaced the soul with heart, unless it was already the reading present in their exemplar.

\subsubsection{Divergences in the renderings of hono $[\mathrm{r} / \mathrm{s}]$, honoris}

The case of hono $[r / s]$, honoris 'honor; esteem, regard; dignity, grace' also appears to enable one to draw some tentative conclusions as to the motivation behind the divergence between MEGPP L and MEGPP D. Verse 28.2 is the only one in which hono $[r / s]$, honoris appears with the meaning of the reverence due to God:

(2) 28.2: Afferte [adferte] domino gloriam \& honorem: afferte [adferte] domino gloriam nomini eius /ejus/, adorate dominum in atrio sancto eius /ejus/.

'Bring to the Lord glory and honor! Bring to the Lord His name's glory. Adore the Lord in His holy palace's courtyard!'

The different treatment of this particular occurrence of hono $[r / s]$, honoris in MEGPP D may, therefore, indicate an effort on the part of the scribe to emphasise its distinct character.

\subsubsection{Divergences in the renderings of miseratio, miserationis}

The divergence as far as the occurrences of miseratio, miserationis 'pity, compassion' are concerned may have been caused by the influence of the French text upon the scribe of MEGPP D. In the French Psalter the word pitie is used only once, precisely in the context where both manuscripts of MEGPP employ the word pite. In the remaining two cases merci is opted for and this is also what happens in MEGPP D - the word merci is selected. MEGPP L's choice of pitē in verse 50.2 does not seem to have been contextually motivated and may reflect scribe's or translator's independent choice.

It might also be of interest to observe that any other contextual considerations do not appear to have caused the divergence. Although it could seem that the noun pite in verse 24.6 was opted for due to the fact that merci was employed in the same verse to render misericordia, misericordiae 'pity, sympathy; compassion, mercy; pathos'(cf. 3), the two co- 
occur also in verse 39.15 , where merci is used by both manuscripts to translate the two Latin nouns (cf. 4).

(3) 24.6: Reminiscere miseracionum $\mid<[$ miserationum $]>/$ tuarum domine: \& mise|recordiarum $\mid<[$ misericordiarum] $>/$ tuarum que $/<q u \propto</$ [quia] a seculo $/<$ se [ae]culo $>/$ sunt.

'Remember Your compassion, Lord, and Your mercy, because they are from the age!'

(4) 39.15: Tu autem domine ne longe facias miseraciones $\mid<$ [miserationes] $>/$ tuas a me: miserecordia $1<$ [misericordia] $>/$ tua \& veritas tua semper susceperunt me.

'But You, Lord, do not make Your compassion far from me! Your mercy and Your truth have always sustained me.'

\subsubsection{Divergences in the renderings of sepulcrum, sepulcri}

The most probable reason for the divergence between the two manuscripts of MEGPP in the case of sepulcrum, sepulcri 'grave, tomb' is the influence of the French text. The noun cercueil 'sarcophagus, a box into which the corpse of the deceased is put to be buried' appears in the French Psalter exclusively in verse 5.11. The remaining occurrences of the Latin noun in question are rendered by sepulcre 'tomb, sepulchre'. Most probably, the scribe of MEGPP L endeavoured to reflect this shift.

As far as the contextual motivation for the divergence is concerned, there appears to be none in the case of the occurrences of sepulcrum, sepulcri. The noun appears twice in the same phrase, i.e. sepulcrum patens est guttur eorum 'their throat is an open grave', in verses 5.11 and 13.5. In the latter it is rendered by biriel( $s$ in both manuscripts, whereas in the former, as presented in Table 1, by grāve and biriel(s in MEGPP L and MEGPP D respectively.

\section{Conclusions}

The objective of this paper was to examine lexical variance in all its complexity between two medieval manuscript copies of a single work. Among the 2877 nouns (in each text), 275, roughly $10 \%$, diverge between MEGPP L and MEGPP D, which means that every tenth noun employed in the two text versions is different from the one employed in the other manuscript. This is a surprising finding from the modern perspective but one which well illustrates Nichols' (2011) postulate to regard medieval manuscripts as exhibiting 'mutable stability'. It forces the modern reader to consider each medieval manuscript text both a reflection of a perfect text, an 'exemplar of a logocentric book-beyond-the-books' (West 2006: 246) and a separate entity at the same time.

Out of the 275 pairs of items mentioned above, 145, representing renderings of 70 distinct Latin lemmata, have been further analysed since they were congruent with the methodology adopted in the research. The conclusions that I have arrived at appear to be consistent with the very nature of the manuscript texts. Variance is as if inherent in them and one cannot account for the majority of the divergences: variation in the renderings of 33 Latin lemmata could not be scrutinised as there were too few occurrences of these nouns. Divergences between the translations of the another 33 nouns do not appear to have been caused by any 
guiding principle, although in the case of one of among those nouns, i.e. disciplina, disciplinae, it cannot be excluded. The variant lexical choices in the case of the renderings of the remaining four Latin lemmata may be tentatively postulated to have been governed by some principles but even these need to be approached with caution.

In sum, thus, the variance between the manuscript copies of MEGPP is extraordinary but there does not appear to be much logic behind their divergent lexical choices. There, after all, seems to be no method in this madness. Manuscript culture is... a world of its own.

\section{References}

Berger, S. 1884. La Bible française au moyen age: étude sur les plus anciennes versions de la Bible écrites en prose de langue d'Oïl. Paris: l'imprimerie nationale.

Black, R. R., and R. C. St-Jacques. (eds.). 2012. The Middle English glossed prose psalter. Heidelberg: Universitätsverlag Winter.

Bülbring, K. D. (ed.). 1891. The earliest complete English prose psalter together with eleven canticles and a translation of the Athanasian creed. Edited from the only two MSS. in the libraries of the British Museum and of the Trinity College, Dublin with preface, introduction, notes and glossary. Part I: preface and text. London: Kegan Paul, Trench, Trübner and Co.

Cerquiglini, B. 1999. In praise of the variant. A critical history of philology, translated by B. Wing. Baltimore: The John Hopkins University Press.

Charzyńska-Wójcik, M. 2013. Text and context in Jerome's Psalters: Prose translations into Old, Middle and Early Modern English. Lublin: Wydawnictwo KUL.

Cunyus, J. G. 2009. The audacity of prayer: A fresh translation of the Book of Psalms (Latin-English edition). Glen Rose: Searchlight Press.

Deanesly, M. 1920. The Lollard Bible and other medieval biblical versions. Cambridge: University Press.

Dictionnaire du Moyen Français, version 2012 (DMF 2012). ATILF - CNRS \& Université de Lorraine. http://www.atilf.fr/dmf

Gellrich, J. 1985. The idea of the book in the Middle Ages: Language theory, mythology, and fiction. Ithaca: Cornell University Press.

Greetham, D. C. 1994. Textual scholarship. An introduction. New York, London: Garland Publishing.

Hanna, R. III., and D. Lawton (eds.). 2003. The Siege of Jerusalem. Early English Texts Society OS 320.

Hanna, R. III. 2003. English Biblical texts before lollardy and their fate. In F. Somerset, J. C. Havens, and D. G. Pitard (eds.), Lollards and their influence in late medieval England, 141-153. Woodbridge: The Boydell Press.

Lis, K. in press. How to measure the French influence - lexical choices in a 14th-century English Psalter. To appear in A. Malicka-Kleparska, M. Bloch-Trojnar, and K. Drabikowska (eds.), Concepts and structures Studies in semantics and morphology. Lublin: Wydawnictwo KUL.

Liuzza, R. M. 2000. Scribal habbit: the evidence of the Old English Gospels. In M. Swan, and E. M. Treharne (eds.), Rewriting Old English in the twelfth century, 143-165. New York: Cambridge University Press.

MED = Kurath, H., S. McAllister Kuhn, J. Reidy, R. E. Lewis et al. (eds.). 1952-2001. Middle English Dictionary. Ann Arbor: University of Michigan Press. http://quod.lib.umich.edu/m/med/

Nichols, S. G. 2009. New challenges for new medievalism. http://www.academia.edu/5470816/ New_Challenges_for_New_Medievalism

Nichols, S. G. 2011. Mutable stability: The paradox of reading \& copying medieval literature. http://www.academia.edu/475271/Mutable_Stability_A_Paradox_of_Reading_and_Copying_Medieval_Lit erature

Nichols, S. G. 2013. What do we mean by variance today? Medieval manuscripts in the Digital Age. http://www.academia.edu/5425936/What_Do_We_Mean_by_Variance_Today 
Nichols, S. G. 2014. What is a manuscript culture? Technologies of the manuscript matrix. http://www.academia.edu/6481950/What_is_a_Manuscript_Culture

OED = Simpson, J., and E. Weiner (eds.). 1989. Oxford English Dictionary. $2^{\text {nd }}$ edition. Oxford: Clarendon Press.

St-Jacques, R. C. 1989. Middle English Glossed Prose Psalter and its French source. In J. Beer (ed.), Medieval translators and their craft, 135-154. Kalamazoo: Medieval Institute Publications.

Sutherland, A. 2015. English Psalms in the Middle Ages, 1300-1450. Oxford: Oxford University Press.

West, W. N. 2006. Old news: Caxton, de Worde, and the invention of the edition. In W. Kuskin (ed.), Caxton's trace: Studies in the history of English printing, 241-274. Notre Dame: University of Notre Dame Press.

Whitaker, W. WORDS: Latin-to-English \& English-to-Latin Dictionary. http://ablemedia.com/ctcweb/showcase/ wordsonline.html

Willis, J. H., Jr. 1992. Leonard and Virginia Woolf as publishers: The Hogarth Press, 1917-1941. Charlottesville: University Press of Virginia. 